\title{
Breaking the Dilemma between Litigation and Non- litigation
}

"Diversified Mechanisms of Dispute Resolution" in Contemporary China

Jieren Hu and Yang Zheng

\section{(2) OpenEdition}

\section{Journals}

Electronic version

URL: http://journals.openedition.org/chinaperspectives/6985

DOI: $10.4000 /$ chinaperspectives. 6985

ISSN: 1996-4617

\section{Publisher}

Centre d'étude français sur la Chine contemporaine

Printed version

Date of publication: 1 June 2016

Number of pages: 47-55

ISSN: 2070-3449

\section{Electronic reference}

Jieren Hu and Yang Zheng, «Breaking the Dilemma between Litigation and Non-litigation », China Perspectives [Online], 2016/2 | 2016, Online since 01 June 2017, connection on 28 October 2019. URL : http://journals.openedition.org/chinaperspectives/6985; DOI : 10.4000/chinaperspectives.6985

(C) All rights reserved 


\title{
Breaking the Dilemma between
}

\section{Litigation and Non-litigation}

\author{
"Diversified Mechanisms of Dispute Resolution" in Contemporary China
}

\author{
IIEREN HU AND YANG ZHENG
}

\begin{abstract}
Focusing on the dispute resolution mechanisms for defusing various social disturbances and collective incidents during the reform period and particularly in the last decade, this paper argues that the Chinese government has adopted pragmatic and problem-solving approaches to designing and developing various mechanisms of dispute resolution in response to the complicated and challenging situation of steadily increasing and intensifying social contention. There is evidence that neither litigation nor non-litigation means of dispute resolution can effectively resolve social conflicts. In light of this difficulty, various experiments have been put in place at the local level to meet social needs and manage social crises while balancing state power and social self-governance. We call such experiments "diversified mechanisms of dispute resolution (DMDR)." This study sheds light on the shift from an emphasis on the earlier non-litigation approach to a more diversified way of addressing collective disputes in contemporary China.
\end{abstract}

\section{KEYWORDS: Diversified Mechanisms of Dispute Resolution, litigation, non-litigation, dispute resolution, social stability, China.}

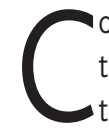
ontinuous economic transformation, new social and cultural practices, and a new round of legal reform reflect an ongoing effort by the Chinese Communist Party (CCP) to enhance the legitimacy of its rule and to maintain social stability under pressure from a large number of domestic social conflicts, serious territorial disputes, and the ever-changing international environment since the reform and opening-up policy was launched in 1978. Unabated economic growth has resulted in a restless population characterised by insatiable expectations. The new generation of scholarship has borne witness to the great variety and increasing intensity of contentious politics in contemporary China. We can see that from 1993 to 2005 , official reports of collective incidents (quntixing shijian 群体性事 件) surged from 8,700 to 87,000, a surprising number of disruptive actions, even with violence, averaging about 250 cases per day. (1) Although the repertoire of Chinese contention still draws on traditional forms of resistance such as street demonstrations, strikes, and petitions, it has expanded to involve new forms such as Internet-based mobilisation. (2) Mass participation against the government is primarily motivated by the exploitative nature of economic development and its negative impact on the poor, because discontent and frustration caused by political and economic hardship compels the weak and poor to protest vigorously. ${ }^{(3)}$ The high frequency of popular protests is related to the governments' inability to settle social problems and defuse social grievances. What the Party-state has done is characterised by a dual attempt to proactively pursue fair and legally justifiable results for Chinese citizens on the one hand, and to contain popular protests and collective action on the other.

This raises a number of questions that are not only debated in the academy on Chinese contentious politics but are also of great significance to the government in seeking effective dispute resolution mechanisms. What is an effective means of dispute resolution in the current Chinese situation?
Are litigation and non-litigation methods still functioning well in resolving social disturbances and collective incidents? What other mechanisms can both citizens and the Party-state use to solve problems while meeting all kinds of social needs and balancing state power and social forces? And what are the institutional conditions for this new kind of mechanisms to work efficiently? These questions are at the root of the social dispute resolution agenda.

By examining existing studies on dispute resolution mechanisms and contentious politics, this paper raises the concept of "diversified mechanisms of conflict resolution" (DMDR) and tries to analyse its rationale and institutional basis in China, where political power is centralised by the Partystate and civil society is relatively weak. DMDR is defined as a zone of convergence of the formal legal system, administrative methods, and social channels that includes informal patterns of bargaining, consultation, and mediation in order to contain the drastically increasing social disputes in Chinese society. What are the characteristics of DMDR compared with other

This article was funded by the 2014 Social Science Research Project of Tongji University, "Nonlitigation Way of Collective Dispute Resolution during Social Transformation - Based on Cases in Yangtze Delta Area" (20141866), and the 2015 Shanghai Social Science Special Research Project for the Training Program of Young and Middle-Aged Cadres, "Improving Grand Mediation Mechanism during the Rule-of-Law Process" (20153501).

1. The collective incidents include strikes, demonstrations, sit-ins, marches, posting slogans, group complaints targeting governmental agencies, surrounding leaders, blocking traffic, and damaging public property, etc. For the increased frequency and size of these incidents, see Jae Ho Chung, Hongyi Lai, and Ming Xia, "Mounting Challenges to Governance in China: Surveying Collective Protestors, Religious Sects and Criminal Organizations," The China Journal, No. 56, July 2006, pp. 1 31.

2. Eytan Gilboa, "Media and Conflict Resolution: A Framework for Analysis," Marquette Law Review, Vol. 93, No. 1, 2009, pp. 97-98.

3. Wooyeal Paik, "Economic Development and Mass Political Participation in Contemporary China: Determinants of Provincial Petition (xinfang) Activism 1994-2002," International Political Science Review, Vol. 33, No. 1, 2012, pp. 99-120. 
dispute resolution methods in defusing popular protests and collective disputes? How does DMDR play its conflict-resolution role by combining judicial, administrative, and social means while balancing power between the government and civil society?

Based on survey data and case studies conducted in three cities in China from June to December 2014, this study tries to address the aforementioned questions by specifying the concrete social processes and institutional mechanisms out of which DMDR emerges and operates through judicial, administrative, and social means; that is, the "active judiciary" and "community judges" implemented in S City, the "People's Mediation Centre" operated in F City, and the "One-Stop Comprehensive Petition Service Station" practiced in T City. Methodologically, these three cases represent judicial, administrative, and social "innovations," respectively. The three cities were chosen for their unique implementation of new mechanisms in dispute resolution and their accessibility to the authors for conducting surveys and interviews. The study draws on the experiment of DMDR in China to shed light on theoretical debates concerning the institutional basis for dispute resolution mechanisms and their limitations in application; it therefore renders a complex mechanism that attempts to resolve the dilemma between litigation and non-litigation in the current situation of dispute resolution, and especially facilitates study of the dynamic interaction between the state and society in contemporary China. Background information is also derived from governmental archives and documents, case files, and media reports.

\section{The institutional basis of DMDR: The dilemma of litigation versus non-litigation}

\section{The limitations of litigation}

The transition to market economy has not only increased transactions and wealth accumulation but has also created conflicts of interest between various parties in China. Despite loopholes and limitations in addressing disputes through litigation, since the promulgation of China's 1991 Civil Procedure Law there has been an increasing number of judicial disputes since the 1990s. ${ }^{(4)}$ The sheer volume of cases has placed significant stress on the judicial system and grassroots courts. ${ }^{(5)}$ Courts have also become fora for airing rights-based grievances, including administrative litigation, collective actions such as strikes and labour protests, and a small number of discrimination claims files directly under the Constitution.

Big changes and bottom-up development have occurred during China's legal reform and institutional experiments. ${ }^{\left({ }^{6}\right)}$ Techniques for settling social disputes include requiring higher qualifications for judges, an emphasis on mediation and conciliation, the strategy of breaking plaintiffs up into smaller groups, and inviting other parties such as trade unions or labour supervision departments to settle disputes in hopes of encouraging reconciliation or even withdrawal of the suit. (7) Some courts also try to pacify protesters through legal means, for example by providing accelerated procedures for accessing government-sponsored funds. ${ }^{(8)}$

It is undeniable that the efficiency of the legal process has increased since reform of the case management system, rules of evidence, time limits for the completion of cases, and various stages of the litigation process. ${ }^{(9)}$ Nevertheless, the extent to which citizens can use litigation to protect their rights and pursue justice is affected by a series of factors that include denial of the right to sue, time-consuming procedures, con- flicting policy goals, and the lack of strength and independence of the courts, etc. Chinese courts, which face chronic difficulties in enforcing judgments, lack the capacity and authority to provide adequate remedies for many complex cases that involve collective or politically sensitive socio-economic claims, vague legal provisions, or complex, intersecting interests of multiple parties and levels of the Party-state. ${ }^{(10)}$ They are, in essence, characterised by a heavy dependence on political and administrative authorities. ${ }^{(11)}$

The failure of the courts has led to litigation abuse (lansong 滥讼) and mass protests, ${ }^{(12)}$ thus forcing citizens to turn to the petitioning system as an alternative choice. ${ }^{(13)}$ Chinese citizens are taking "boundary-spanning" actions that occupy a grey zone between accepted and transgressive contention by citing central laws and policies, leveraging elite allies, and applying multiple and escalating measures to challenge local injustices. ${ }^{(14)}$

Combined with a drastic increase in the number of petitions, petitioners may seek relief from a wide variety of sources, including Party organs, government agencies, the procuratorate, and the courts. ${ }^{(15)}$ The result has been a "petitionised judiciary" (sifa xinfanghua 司法信访化) characterised by a strong petitioning and weak judicial system (qiang xinfang ruo sifa 强信访 弱司法). This, in turn, can only result in exacerbation of social disturbances and disruptive actions, increasing pressure on the courts and the local gov-

4. Zhu Jingwen (ed.), Zhongguo falü fazhan baogao (1979-2004) (China Legal Development Report [1979-2004]), Beijing, Renmin University of China Press, 2007; Xie Jun and Sun Lijuan, "Access to Collective Litigations in China: A Tough Work," Journal of Politics and Law, Vol. 3, No. 1, March 2010, pp. 45-55.

5. "Beijing susong shuliang baozha shi zengzhang: qunian $76 \%$ anjian weineng jie'an" (The number of cases in Beijing increases explosively: The percentage of unclosed cases increased by $76 \%$ last year), Xinhuanet, http://news.xinhuanet.com/legal/2005-04/27/content_2884636.htm (accessed on 29 March 2016); also see "Wuxi laodong zhengyi anjian baozha shi zengzhang: lanyong su quan huoshi chengyin zhiyi" (The explosive growth in labour disputes in Wuxi:Abuse of the rights of litigation may be one of the causes), Jschina.com.cn, http://news.jschina.com.cn/ system/2014/07/21/021441129.shtml (accessed on 6 February 2012).

6. Benjamin L. Liebman, "China's Courts: Restricted Reform," The China Quarterly, No. 191, September 2007, pp. 620-638.

7. Chen Feng and Xu Xin, "'Active Judiciary': Judicial Dismantling of Workers' Collective Action in China," The China Journal, No. 67, January 2012, pp. 87-109.

8. Ching Kwan Lee, "From the Specter of Mao to the Spirit of the Law: Labor Insurgency in China," Theory and Society, Vol. 31, No. 2, 2002, pp. 189-228.

9. Supreme People's Court Report 2007, http://news.sina.com.cn/pc/2007-03-13/326/152.html (accessed on 10 February 2016).

10. Keith J. Hand, "Resolving Constitutional Disputes in Contemporary China," University of Pennsylvania East Asia Law Review, Vol. 7, No. 1, November 2011, pp. 51-159; Ng Kwai Hang and He Xin, "Internal Contradictions of Judicial Mediation in China," Law \& Social Inquiry, Vol. 39, No. 2, Spring 2014, pp. 285-312; Su Yang and He Xin, "Street as Courtroom: State Accommodation of Labor Protest in South China," Law and Society Review, Vol. 44, No. 1, March 2010, pp. 157-184.

11. Peter Solomon, "Authoritarian Legality and Informal Practices: Judges, Lawyers and the State in Russia and China," Communist and Post-Communist Studies, Vol. 43, No. 4, December 2010, pp. 351-362; Chen Feng and Xu Xin, "'Active Judiciary': Judicial Dismantling of Workers' Collective Action in China," art. cit., p. 89.

12. Recent reports from courts in China show that abuse of procedure rights and malicious prosecution have become more serious. The 2012 Civil Procedure Law has been revised to take restrictive measures and address this problem. The number of mass protests rose rapidly as well. See Liu Xiaomei, "Guanyu Zhongguo goujian shehuizhuyi hexie shehui jincheng zhong quntixing shijian de fashehuixue sikao" (Legal sociological thoughts on the mass incidents in the process of establishing socialist harmonious society in China), Huizhi canyu zhongxin (Participation.cn), 2 January 2014, www.participation.cn/liluntantao/lunwen/14588.html (accessed on 12 February 2016).

13. Carl Minzner, "Xinfang: An Alternative to the Formal Legal System," Stanford Journal of International Law, No. 42, 2006, pp. 117-118; Ying Xing, "Zuowei teshu xingzheng jiuji de xinfang jiuji" (Xinfang remedy as a special administrative remedy), Faxue yanjiu (Chinese Journal of Law), No. 2004/3, pp. 58-71.

14. Kevin O'Brien and Li Lianjiang, Rightful Resistance in Rural China, New York and Cambridge, Cambridge University Press, 2006.

15. Randall Peerenboom and Xin He, "Dispute Resolution in China: Patterns, Causes, and Prognosis," East Asia Law Review, Vol. 4, No.1, Spring 2009, pp. 38-40, https://www.law.upenn.edu/journals/ ealr/articles/Volume4/issue 1/PeerenboomHe4E.AsiaL.Rev.1\%282009\%29.pdf (accessed on 10 February 2016). 
ernment due to the upsurge in petitions, the large number of lawsuits, and the escalation of collective action. ${ }^{(16)}$

As formal channels for dispute resolution are ineffective, the accumulation of conflicts, if not handled properly, could threaten social stability and economic development in China. The Party-state's obsession with stability has ultimately boomeranged as social contention and collective actions have intensified throughout the country.

\section{The predicament of non-litigation}

Given the inefficiency of the judiciary and the skyrocketing incidence of social unrest, political-legal leaders have noted that not only judicial but also extrajudicial means such as mediation, arbitration, administrative reconciliation, consultation, negotiation, and government intervention are key components of a multifaceted social management system designed to address public anger, alleviate conflicts, and achieve the paramount goal of maintaining political stability and social harmony. ${ }^{(17)}$ Theorists of contentious politics have also recognised that alternative dispute resolution may offer advantages in addressing different types of problems, as it provides greater flexibility to take account of non-legal factors and develop creative remedies that could promote more productive resolution outcomes than would be possible through adjudication. ${ }^{(18)}$

Mediation has long been the favoured method for Chinese citizens to address disputes since the 1980s. However, this prominent mechanism of Chinese dispute resolution that plays a central role in reconciling conflicting parties has fallen into decline with changing social conditions. ${ }^{(19)}$ The fundamental reason for the decline of mediation is that it has come to be seen as inconsistent with rule of law in that mediation results are not necessarily any easier to enforce than final judgments, and it has become a stalling tactic for noncompliant parties. ${ }^{(20)}$ Moreover, the people's mediators lack legal training and specialised knowledge. Procrastination in the implementation of mediation results typically breeds distrust, scepticism, and acrimony and undermines the enforcement of mediation agreements. Some scholars even suggest that mediation should yield to adjudication that clearly defines the rights, duties, and liabilities of the parties in a dispute. (21)

In addition to mediation, we have seen an emergence of a range of consultative and deliberative methods in China performing more effectively in reducing social protests and defusing citizens' grievances at the grassroots level while strengthening the government's capacities. ${ }^{(22)}$ The establishment of a Grand Mediation mechanism (datiaojie 大调 解), public hearings (tingzhenghui 听证会),Wenling's Deliberative Poll, the China Public Budget Reform Program (CPBR), and the Yiwu City Federation of Trade Unions, for example, has demonstrated that the degree of reliance on the "supremacy of law" and the "rigidity" of the law is now decreasing with the mushrooming of more flexible methods of dispute resolution. ${ }^{(23)}$ These new mechanisms provide citizens with alternative methods to seek dispute resolution and avoid the complex, unpredictable, and time-consuming procedures that litigation requires. However, some Chinese scholars have raised concerns that such practices aimed at creating "rigid stability" (gangxing wending 刚 性稳定) for the country could ultimately undermine the authority of the law, the legal rights of the parties, the neutrality of the courts, and the voluntary nature of the mediation process. More specifically, as the source of legal-administrative personnel overseeing the mediation process, government intervention may raise worries about the neutrality and objectivity of the resolution results. ${ }^{(24)}$
Failure to address their disputes and pursue their demands, and particularly the lack of power and political resources to gain compensation through institutionalised methods, often leads citizens to choose noninstitutionalised methods such as exposing their grievances to the media, requesting help from foreign organisations, or even taking violent action to seek intervention from higher levels of government. ${ }^{(25)}$ Nevertheless, effective mechanisms of dispute resolution are still lacking in spite of the continuous creation of new methods, the reform of existing mechanisms, and the return to older mechanisms when newer ones prove disappointing. (26) The form of Alternative Dispute Resolution (ADR) originating in the United States has also been introduced and promoted by Chinese scholars and officials to resolve disputes in a non-confrontational way. (27) The principal difference between Chinese ADR and American ADR lies in the broad application of mediation principles during the entire process of dispute resolution and within the court or tribunal that handles the case, rather than by an independent organ before the hearing. The inevitable outcome is therefore strong state intervention and political pressure on the ADR process. Citizens may be forced to make concessions and compromise without a resolution of the root cause of the problem.

Quite a few Chinese scholars have promoted alternative methods of dispute resolution, and they tend to overemphasise non-litigation aspects and

16. Xing Huanzhong, "'Sifa xinfanghua' qushi yinfa danyou" (Worries raised by the petitionised judicial system), Xing bian, 5 December 2010, http://defenselawyer.com.cn/?p=1525 (accessed on 10 February 2016)

17. Keith J. Hand, "Resolving Constitutional Disputes in Contemporary China," art. cit., pp. 135; 136; Hualing Fu and Richard Cullen, "From Mediatory to Adjudicatory Justice:The Limits of Civil Justice Reform in China," in Margaret Y.K. Woo and Mary E. Gallagher (eds), Chinese Justice: Civil Dispute Resolution in Contemporary China, New York, Cambridge University Press, 2011.

18. Lon Fuller, "The Forms and Limits of Adjudication," Harvard Law Review, Vol. 92, No. 2, December 1978, pp. 395-410; Fan Yu, "Fei susong jiufen jiejue jizhi (ADR) yufazhi de kechixu fazhan: jiufen jiejue yu ADR yanjiu de fangfa yu linian" (Non-litigation dispute resolution mechanisms [ADR] and the sustainable development of rule of law: Method and idea of researches on dispute resolution and ADR), Fazhi xiandaihua yanjiu (The Study on Legal System Modernisation), No. 00, 2004.

19. Fan Yu, "Dangdai Zhongguo fei fusong jiufen jiejue jizhi de wanshan yu fazhan" (Improvement and development of non-litigation dispute resolution in contemporary China), Xuehai (Academia Bimestris), No. 1, 2003, http://wenku.baidu.com/view/68d48d2d453610661ed9f4ff.html?re=view (accessed on 6 February 2016); Xiaohua Di and Yuning Wu, "The Developing Trend of the People's Mediation in China," Sociological Focus, Vol. 42, No. 3, August 2009, pp. 228-245.

20. Randall Peerenboom and Xin He, "Dispute Resolution in China: Patterns, Causes, and Prognosis," art. cit., p. 25.

21. Stanley Lubman, "Bird in a Cage: Chinese Law Reform after Twenty Years," Northwest Journal of Law and Business, Vol. 20, No. 3, Spring 2000, pp. 383-423.

22. Baogang He, "Participatory and Deliberative Institutions in China," in Ethan J. Leib and Baogang He (eds), The Search for Deliberative Democracy in China, New York, Palgrave Macmillan, 2006.

23. Jieren Hu, "Grand Mediation: Mechanism and Application," Asian Survey, No. 51, November 2011, pp. 1065-1089; Baogang He and Mark E. Warren, "Authoritarian Deliberation:The Deliberative Turn in Chinese Political Development," Perspective on Politics, Vol. 9, No. 2, June 2011, pp. 274-280; Baogang He, "Western Theories of Deliberative Democracy and the Chinese Practice of Complex Deliberative Governance," in Ethan J. Leib and Baogang He (eds), The Search for Deliberative Democracy in China, op. cit.

24. Yu Jianrong, "Dangqian yali weiwen de kunjing yu chulu" (Reassessing Chinese society's "rigid stability": Stability preservation through pressure: Its predicament and the way out), Tansuo yu zhengming (Exploration and Free Views), Vol. 9, 2012, pp. 3-6.

25. Ren Bingqiang, "Nongcun huanjing kangzheng shijian yu difang zhengfu zhili weiji" (Environmental protests in rural area and the crisis of local governance), Guojia xingzheng xueyuan xuebao (Journal of China National School of Administration), Vol. 5, 2011, pp. 98-102; Yu Jianrong, Kangzhengxing zhengzhi: Zhongguo zhengzhi shehuixue jiben wenti (Contentious politics: Basic questions in Chinese political sociology), People's Publishing House, 2010.

26. Randall Peerenboom and Xin He, "Dispute Resolution in China: Patterns, Causes, and Prognosis," art. cit., p. 2.

27. Fan Yu, ADR Yuanliyu Shiwu (ADR Principles and Practices), Xiamen, Xiamen University Press, 2002; Fan Yu, Fei susong jiufen jiejue jizhi yanjiu (Study on non-litigation dispute resolution mechanisms), Beijing, Renmin University Press, 2000. 
even suggest substituting litigation with other dispute-resolution mechanisms such as arbitration, mediation, and self-remedy. Moreover, the existing literature seldom takes the institutional foundations of the various dispute resolution methods into consideration and thus neglects the dynamic interaction between strong government and weak citizenry in the dispute resolution process. Nor has any English-language study filled this gap theoretically or empirically. This paper describes dispute resolution methods that organically integrate formal and informal judicial, administrative, and social measures, which we call Diversified Methods of Dispute Resolution (DMDR). These methods aim at minimising costs and maximising the odds of resolving disputes fairly and effectively, notably by leveraging interpersonal relations and informal social networks.

\section{The rationale and operationalisation of DMDR}

Litigation through lawsuits in court and non-litigation/ADR by negotiation, consultation, mediation, and arbitration are not separated in China as they may be in other political contexts. This is due to the lack of an active civil society under authoritarian rule with strong political control. (28) In the Chinese context, more effective means of dispute resolution depend to a large extent on the participation of social organisations and the cooperation of various parties, including the courts, the government, and social forces. ${ }^{(29)}$ The concept of DMDR is a device conceived in the contemporary challenging conditions to understand how the state tries to resolve social conflicts and reduce the level of opposition while facilitating dialogue with the various strands of society. It is characterised as a hybrid system of dispute resolution that encompasses a large variety of dispute resolution methods of different types, functions, procedures, and formats that complement and coordinate with each other to defuse and address social disputes and attempt to meet various social needs during the dispute resolution process. It unifies litigation and non-litigation methods by combining the judicial, administrative, and social systems and works through an interactive process involving top-down decision-making by the Party-state, grassroots pressure, and citizen-state dialogue and compromise.

Although DMDR may be considered just another type of top-down political arrangement by the authoritarian regime to strengthen its control over society, it is often presented as combining the judicial method, which is the most formal and relatively fair method for resolving disputes in Chinese society, the administrative method, which enjoys higher authority and has become more commonly used by citizens, and the social mechanism, characterised by new forms of dispute resolution.

This paper will detail three cases to illustrate how DMDR operates to resolve conflict and relieve social grievances effectively. S, F and T City are three large cities with more than 18 districts in central and eastern China. We choose these three cities based on their unique implementation of DMDR and their accessibility to our field research. "Active judiciary" and "community judges" in S, the "People's Mediation Centre" in F, and the "OneStop Comprehensive Petition Service Station" in T represent judicial, administrative, and social means of managing social disputes, respectively. In-depth interviews with judges, government officials, and local citizens were conducted from May to October in 2014 to obtain information on efforts to manage social disputes in particular organisations, and to draw implications.

\section{Case 1: The judicial method of DMDR: "Active judiciary" and "community judges" in S City}

Given that Chinese courts bear the major burden in resolving social disputes and maintaining stability, grassroots courts have engaged in judicial experiments to fulfil their political mission and actively engage in conflict resolution. One famous example is the system of "community judges" (CJ) (shequ faguan 社区法官) originated in Dongguan, Guangdong Province, in southern China, which since March 2009 has spread to many cities such as Suzhou, Nanjing, Foshan, Shanghai, and Chongqing.

The CJ concept is derived from the "Judiciary in the Community" of the judiciary of England and Wales. ${ }^{(30)} \mathrm{CJs}$ in China are distinguished by facing more political tasks in fulfilling the "three top priorities" (san ge zhishang 三个至上) ordered by the Chief Justice of the Supreme People's Court (SPC), which means that utmost priority must be given to the Party's cause, the people's interests, and the Constitution. These three priorities guiding judicial practice show that the Party's goals and concerns override all else. With the aim of innovating social management and promoting an active judiciary, the courts in S City try to combine litigation with non-litigation mechanisms by sending judges to provide mediation between conflicting parties and resolve disputes in local communities. (31)

CJs are dispatched on a voluntary basis but are required to be seasoned judges with full experience in handling cases and a passion for mediating and resolving disputes. Moreover, they should be familiar with the local communities and able to speak the dialect of local citizens so that mutual trust can be built up. CJs allow the courts to extend their power beyond the courtrooms. In particular, the judges play three key roles of prevention, resolution, and education by mediating and adjudicating disputes in local communities. All three roles are integrated into the $\mathrm{C}$ system, which combines administrative, judicial, and social authority to deal with social disputes.

CJs are sent to local communities by the district court and work with the Community Legal Aid Centre (CLAC) organised by ten retired judges. According to statistics from the street-level judicial office in $\mathrm{N}$ community, which is in charge of local dispute mediation and conflict resolution, after sending CJs to N community from the district court and the CLAC in 2009, the number of disputes, collective incidents, and petitioning cases received by mediation organisations in the judicial office decreased by $38.4 \%, 50 \%$, and $63.6 \%$, respectively (see Table 1). This shows that the specialised mediation skill of the CJs, combined with the judges' authority, helps to achieve results among conflicting parties compared with traditional mediation by the people's mediators, who are usually retired cadres from local government or members of residents' committees in local communities.

As the Chief Justice of the District Court in S City, Mr. Chen, put it: ${ }^{(32)}$

The total number of civil disputes received by the court in S City increased from 44,002 in 2009 to 50,522 in 2010. Facing a huge num-

28. Baogang He, "Western Theories of Deliberative Democracy and the Chinese Practice of Complex Deliberative Governance," art. cit., p. 139.

29. Baogang He, The Democratic Implications of Civil Society in China, London, MacMillan, 1997.

30. See Courts and Tribunals Judiciary [UK], "Diversity and Community Relations Judiciary," www.judiciary.gov.uk/you-and-the-judiciary/judiciary-within-the-community/diversity-and-communityrelations -judiciary (accessed on 5 February 2016).

31. S City was chosen because it is a typical place where the $\mathrm{C}$ system is fully practiced. As of June 2012, more than 140 towns, streets, and communities were using CJs to deal with all kinds of social disputes.

32. Interview with Mr. Chen in S City, 22 June 2014. 


\begin{tabular}{|l|c|c|}
\hline & $\begin{array}{c}\text { March 2009 } \\
\text { without } \\
\text { CJ system }\end{array}$ & $\begin{array}{c}\text { March } 2010 \\
\text { after } \\
\text { starting } \\
\text { CJ system }\end{array}$ \\
\hline Number of cases received by Judicial Office & 198 & 122 \\
\hline Number of mediated cases by CJs & 30 & -38.4 \\
\hline Number of cases successfully mediated by CJs & 9 & 50 \\
\hline Successful mediation rate & 0.3 & +133.3 \\
\hline Number of collective incidents received by Judicial Office & 4 & 0.8 \\
\hline Number of petitions received by the Judicial Office & 11 & +522.2 \\
\hline
\end{tabular}

Data were collected through field work in N Community of S City. Information was also collected from interviews with CJs and officials in the street-level judicial office.

ber of cases and the potential escalation of social disputes, judges have a great burden in handling cases. The idea of encouraging judges to go to the communities could effectively prevent potential problems and resolve disputes in a diversified form beyond adjudication. This is our idea of the "Court+N" mode that expands the function of the court in managing social disputes.

A labour dispute case in $\mathrm{N}$ community of $\mathrm{S}$ City shows how an active judiciary and CJs help to defuse social disputes and how local CJs balance their task of dispute resolution with their professional obligation to pursue justice.

In June 2009, a textile enterprise in S City suffered a financial crisis and faced bankruptcy, leaving 1,000 workers unpaid and bearing over 4 million yuan in debt. A large number of workers gathered together and requested compensation and future subsistence from the enterprise and the local government. After becoming aware of the workers' protest, officials from the Xinfang (Letters and Visits, i.e. petitions) Department of S City and two judges specialising in company law and labour law from the court and CLAC came to the locality and tried to get the situation under control. The officials and judges calmed the workers and then talked face-to-face with them.

Given their specialised knowledge in managing tough problems, they first froze the company's assets, ordered all of the locks on the company's gate to be changed, and then asked the neighbourhood committee to guard the company's assets pending further legal action. Working as mediators, the judges explained to the protesters that the aim of all of these measures was to protect their legitimate rights and ensure that they could eventually receive compensation. The workers insisted on petitioning with more relatives until the judge from the CLAC gave them suggestions on what strategies they should use according to labour law and guaranteed that they would receive compensation if they ended their collective action. Officials from the local government also persuaded the workers to use what they call more "rational" means of rights protection rather than pushing for a higher, but uncertain, level of compensation. After mediation by the judges and officials, the protest finally ended. Mr. Zhang, a protest leader, told us: ${ }^{(33)}$

Our aim in protesting is quite simple, that is, to get more compensation. We do not intend to violate the law; neither do we want to make things worse. Compared with litigation, it costs much less to have mediation by $\mathrm{CJ}$ s. It especially saves us time and money.
We truly appreciate their free service to us, and we admire them too.

In S City, the court, government agencies, and social organisations constructed a framework for managing social disputes. This demonstrates a pattern of collaborative mechanism adapted to the local context, aimed at reducing the court's burden in dealing with a huge number of cases and extending its function to the grassroots to prevent and defuse collective incidents and social disputes.

\section{Case 2: The administrative method of DMDR: The "People's Mediation Centre" in F City}

In China, there have been various administrative ways of addressing disputes, of which the most common method is administrative remedy, including administrative review and compensation, administrative mediation and arbitration, administrative appeals, and petitions. The Chinese petitioning system is a special means of seeking justice through citizens' demonstrations and protests to request dispute resolution from the government. However, in F City as well as in other urban areas, the reality is that the authorities are overwhelmed by the increasing number of petitions and have become seriously concerned that social stability will be undermined if too many people block government agencies and interrupt officials' daily work. In an effort to reduce instability and perceived threats to the Party-state, the Chinese judiciary has strengthened controls over the courts and other legal institutions, and has instructed them to consider political and social impact, in addition to law, in dispute resolution, and has encouraged diversified methods of solving social problems. The result has been a push to choose mediation and arbitration instead of adjudication. $\mathrm{H}$ District in $\mathrm{F}$ City was selected to illustrate how the district government has cooperated with the district judicial bureau to address administrative disputes by establishing a "People's Mediation Centre" (PMC) (renmin tiaojie zhongxin 人 民调解中心) under the District Joint People's Mediation Committee in October 2008. H District is famous for its systematic web of dispute resolution, in which diverse parties work together to mediate cases that 1) involve complex, difficult, and collective disputes; 2) target government organs or

33. Interview with Mr. Zhang in S City, 3 September 2014 


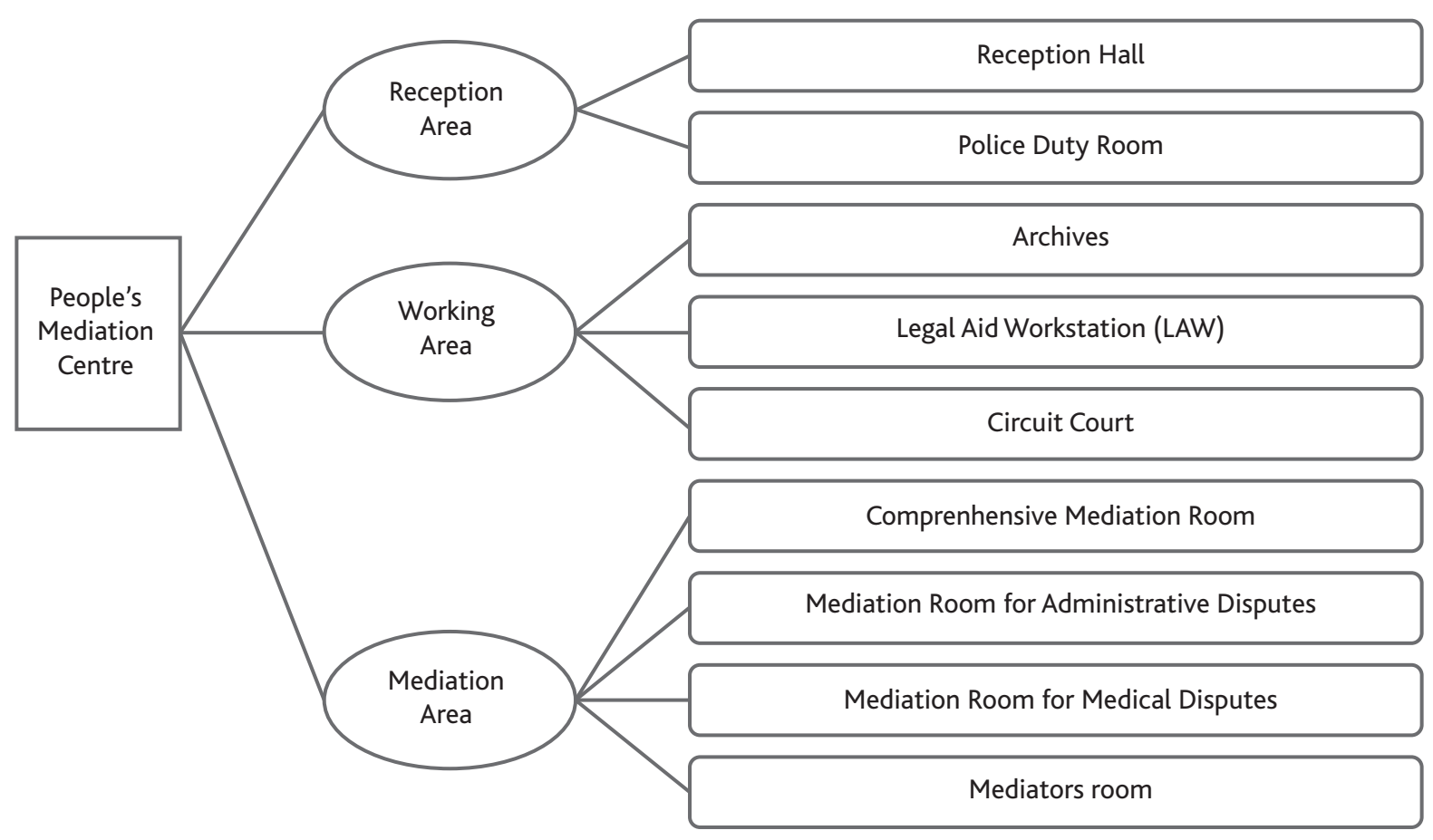

Designed by the authors.

administrative departments in $\mathrm{F} ; 3$ ) may have a major impact on social stability and harmony; 4) involve unclear legal rules that are difficult to apply or enforce; and 5) touch on sensitive issues or violent actions. The PMC was constructed to help reduce collective actions, resolve collective conflicts, and keep social order and stability. As the director of PMC in F City, Mr. Wang, said: (34)

The PMC was established with the support of the district Party committee and the district government. The PMC staff are comprised of university law school graduates with experience and skill in mediation. At the same time, we also recruit deputies of the National People's Congresses (NPC), members of the Chinese People's Political Consultative Conference (CPPCC), public lawyers, community leaders, and chief mediators. Moreover, judges from the court, lawyers from law firms, and volunteers from social organisations are also included to mediate labour disputes, administrative lawsuits, minor criminal cases, etc., in addition to offering legal assistance, counselling, and legal aid in civil cases.

The PMC has three main working areas with nine function rooms to receive and manage all kinds of cases. In particular, two specialised mediation rooms have been set up for managing administrative disputes and medical disputes, which are hard to resolve and need more skill and knowledge in settling these problems. Among the nine function rooms, the "Legal Aid Workstation" (LAW) (falü yuanzhu gongzuo zhan 法律援助工作站) was established in September 2012 with experts in law offering legal aid to conflicting parties. Services provided by LAW also include legal counselling, drafting legal documents and advisory papers, and providing legal aid in non-litigation cases, etc. Graph 1 depicts the working structure of the PMC in H District.
Since it began operating in 2008 , the PMC has received 1,432 social disputes from judicial, administrative, and industrial areas, of which 1,379 were resolved and signed mediation agreements with judicial enforcement, with a successful mediation rate of $96.8 \%$. In particular, from 2008-2012, the PMC played an important role in preventing collective incidents by successful mediation and therefore avoided more than 58 million yuan in economic loss, according to local government figures (see Table 2).

The second case was used to demonstrate the PMC's role in defusing collective incidents targeting the H District government. In spring 2011, Highway Construction Group S signed a contract with the H District government of $\mathrm{F}$ City to construct an expressway downtown. Part of project was subcontracted to a private company - P Construction Team. The two companies had conflicting opinions due to the uneven distribution of work and payment. When talks broke down, $P$ demanded termination of the contract, but $S$ refused. On 20 March, armed workers from P Construction Team gathered in front of $S$ Group and threatened to fight with workers of $S$ Group. The head of S Group immediately turned to the local government for help, afraid that the situation would escalate.

As soon as the $\mathrm{H}$ District government received the information, it reported the case to the PMC. The PMC immediately organised a mediation team with lawyers and mediators from LAW and arrived at the spot very quickly. After talking with the head and worker representative of $\mathrm{P}$, one lawyer from LAW explained the legal procedure for terminating a contract and persuaded them not to use violence, because if anybody involved in the dispute got hurt, someone would have to bear criminal responsibility. Local government officials also tried to help both parties reach a consensus on how to distribute work and payment. Finally, the workers and head of $P$ agreed to

34. Interview with Mr. Wang in H District, F City, 14 August 2014. 
Table 2 - Number of disputes prevented by PMC from 2008-2012

\begin{tabular}{|l|c|c|}
\hline & Cases & People \\
\hline Preventing collective petitions & 23 & 411 \\
\hline Preventing collective disputes & 56 & 827 \\
\hline Preventing civil and criminal cases & 19 & 25 \\
\hline Preventing unnatural death & 11 & 25 \\
\hline
\end{tabular}

Data were collected from the local government of $\mathrm{H}$ District in F City.

a more equitable distribution and promised to stop collective action during the construction project by signing the mediation agreement on 21 May. With the collaborated effort of government officials, mediators, and legal experts from the PMC, this potential dispute was successfully prevented and resolved. The leader of the Xinfang Bureau of $\mathrm{H}$ District, Ms. He, shared her feelings: ${ }^{(35)}$

Chinese people are accustomed to seeking help from the government when they encounter conflicts. This made government officials feel overwhelmed with dealing with disputes and receiving complaints all the time. In recent years, local people have turned to choosing the courts to address their problems, but this actually creates a heavy burden on the court to manage and resolve these cases. We aim at integrating all kinds of manpower and resources to resolve social disputes and build a harmonious community, and that's why the PMC was established and operated.

\section{Case 3: The social mechanism of DMDR: "One-stop Comprehensive Petitioning Service Station" in T City}

In an authoritarian regime with a top-down, state-centric political system, civil society and non-governmental organisations have always been considered weak in China. But in recent years, with China's rapid economic development, quite a lot of social organisations and NGOs have emerged despite the absence of a vibrant civil society conducive to democratisation. This shows that civil society in China is incipient yet dynamic. (36)

Data from the Civil Affairs Bureau in T City shows there are more than 4,000 social organisations performing various functions, of which $40 \%$ specialise in mediation and dispute resolution and $60 \%$ provide community services for the elderly, children, disadvantaged groups, etc. In October 2010, the D District government established a "One-stop Comprehensive Petitioning Service Station" (OCPSS) (yi zhan shi zongzhi xinfang fuwu zhan站式综治信访服务站), which is a government-sponsored, non-profit organisation registered under the Civil Affairs Bureau in T City that specialises in providing mediation service and addressing social disputes. Since the local government strongly encourages social forces to share the government's burden in social disputes, about $40 \%$ of the funding for the OCPSS's operation comes from civil donations for public welfare from local enterprises, and $60 \%$ is subsidised by the Civil Affairs Bureau. The OCPSS staff are comprised of volunteer mediators, legal experts such as lawyers and judges, and officials from the Comprehensive Control and Management Office (zonghe zhili bangongshi 综合治理办公室), Xinfang Bureau, and Judicial Office at the district level. The OCPSS is based on a working centre along with five administrative and judicial organisations, i.e., Comprehensive Control and Management Office, Xinfang Bureau, Judicial Office, police station and the court, which provide one-stop service for receiving complaints and addressing social disputes in local communities. The aim of establishing the OCPSS is to integrate resources and realise what they call " $5+\mathrm{N}$ " impact on defusing citizens' grievances and maintaining social stability, that is to say, the combined impact of the five administrative and judicial organisations would be greater than the sum of their separate actions.

Once the OCPSS centre detects or receives a dispute, it records and registers the information on each case. A specially formulated method of dispute management is then designed based on the nature of the problem. The OCPSS also transfers intractable disputes to higher-level agencies or judicial departments, requiring prompt feedback within one week for common issues and 30 days for complicated ones. As of 2014, more than 240 streets and towns and more than 5,000 local communities in T City had established OCPSSs to help handle social disputes.

The implementation of OCPSS reflects the state's effort to create and use social organisations to defuse social contention, and aspires to "innovation in social management" (shehui guanli chuangxin 社会管理创新) by local government. One new mechanism of "social innovation" in T City is to invite social workers involved in defusing popular grievances particularly related to urban demolition and relocation disputes during the xinfang process. This new way of inviting social workers into petitioning cases has also been practiced in Shanghai, Guangdong, and Shenzhen. The OCPSS plays a coordinated role for connecting social workers from professional social work organisations and government agencies, women's federation and xinfang bureaus in particular, to manage collective disputes by helping petitioners help themselves (zhuren zizhu 助人自助) by means of the government purchasing services from social organisations (zhengfu goumai fuwu 政府购买 服务). (37) Social work organisations sign contracts with the local government, guaranteeing to relieve or resolve $90 \%$ of the disputes they receive and obtaining subsidies from the local government of 12,000 yuan per year. Despite being initially a political arrangement for maintaining social harmony, the intervention of a social service organisation in dispute resolution embodies a kind of state-society cooperation at the local level. The OCPSS is a case in which we can see how recent local experimentation with DMCR modifies contentious situations by using social methods as an alternative means of dispute resolution. The third case, which is a collective dispute caused by a traffic jam, illustrates this.

In October 2009, hundreds of people gathered at the gate of the D District government in T City, demanding compensation from the government for the death of a ten-year-old boy in a traffic jam. The boy's parents, Mr. and Mrs. Gong, launched the protest and demanded that the police pay 100,000 yuan in compensation for their son's death, as he was hit by a police car. The OCPSS sent mediators, lawyers, and social workers to communicate with this couple and provide psychological and emotional support as soon as the centre received information on the case. After talking to the boy's parents and relatives, officials from local government expressed their full

35. Interview with Ms. He in F City, 3 August 2014.

36. Guobin Yang, "The Co-Evolution of the Internet and Civil Society in China," Asian Survey, Vol. 43, No. 3, May 2003, pp. 405-422; Fengshi Wu and Kinman Chan, "Graduated Control and Beyond: The Evolving Government-NGO Relations," China Perspectives, No. 2012/3, pp. 9-17.

37. Susan S. Manning, "The Social Worker as Moral Citizen: Ethics in Action," Social Work, Vol. 42, No. 3, May 1997, pp. 223-230. 
understanding and sympathy to the family while at the same time telling them that their excessive demands were not realistic and that things must be done according to law, since their son also bore responsibility for the accident. The lawyers and mediators also promised to try to get the couple compensation for their loss through the traffic laws if they stopped their demonstration and collective action. The boy's relatives at first insisted on protesting until social workers offered to help them arrange the funeral and consoled them through psychological assistance and support from the community. In addition, the vice-director of the local women's federation contacted the boy's mother directly, asking after her and offering financial support in a way that touched the mother emotionally.

The boy's parents finally agreed to stop petitioning and signed the mediation agreement after the police apologised for the accident and agreed to pay compensation of 20,000 yuan to the family for medical expenditures and the funeral, along with another 5,000 yuan as an additional pension for the family. This agreement was then authorised by the local court and made binding on both parties. When staff from the OCPSS gave the money to the boy's parent, mediators asked each of the protesters to sign a legally binding document promising not to protest any longer. Mrs. Gong told us: ${ }^{(38)}$

I suffer in agony over my son's death. In fact, no compensation can restore his life. I've shown my gratitude to the social workers from the OCPSS; they are quite nice and different from the government. We trust them much more than officials. We decided to stop protesting because I feel they are sincere and they've apologised for my son's death. I do not know much about the law and I do not know how to sue the police. Since the compensation is reasonable according to law, as I was told by the lawyer, I hope my son will rest in peace. I do not want to make things worse. The mediators also helped us, as they told me it is useless to protest illegally and that they could mediate between our family and the police.

It can be seen that social workers in the OCPSS perform a special role during the mediation process, as they can build up mutual trust with the petitioners by providing emotional and psychological support as well as other support that can console them. Social forces, to a large extent, help to relieve social contention as they are viewed as independent and considerate compared with government officials. However, in the Chinese setting, cooperation with the government can bring in more political resources and use extrajudicial means for resolving problems.

\section{DMDR in practice and its implications}

The three cases represent the operationalisation of DMDR, which organically integrates adjudication, mediation, and social means of dispute resolution. The "active judiciary" of CJs handling disputes in local communities shows a mediation process initiated by court judges that incorporates mediation as a supplementary mechanism to adjudication in resolving disputes, in spite of an inherent conflict in the judge taking on the role of both judge and mediator. The reason why judges were able to stop the workers' protest within a short time is that they enjoyed judicial authority as representing the court's decision in the minds of local people. Workers tend to trust judges more than mediators because they see the latter as actually being government officials aiming to oppress disadvantaged groups. In this sense, "active judiciary" means that judges and courts do not simply adju- dicate disputes but deal with them in a way that achieves quicker and costfree resolution. It can enhance communication and interaction between conflicting parties and eliminate "destabilising factors" at the local level. It is also undeniable that more choices and freedom are provided, since people can choose among different forms of dispute resolution. In this sense, DMDR can help reduce confrontations between the state and civil society by providing alternative choices for citizens to make up for the limitations of adjudication and mediation. ${ }^{(39)}$

However, using judge-mediators to settle civil disputes would undermine their authority and affect their impartiality as judges. Moreover, the exercise of state power by local bureaucrats under the guise of mediation would damage the rule of law at the local level. Ms. Huang, the protest leader in the labour dispute, puts it frankly: ${ }^{(40)}$

We finally accepted the resolution method suggested by the community judges. To tell the truth, even if up to now I still have not gotten the money back and no party has given us compensation for our work, we are clear about the situation. Sometimes going to court still does not work. It is even dangerous to take large-scale collective action and make unreasonable demands. We are also afraid of being arrested. Compared with government officials, we tend to believe in local judges. They have more conscience and morality, they will not cheat us, and they will try to solve our problems. But we will insist on protesting and even go to Beijing if they let us down!

The mediation office in local communities signals the decentralisation of state power to the grassroots level for the sake of greater freedom and diversification in resolving collective disputes. The basic characteristic of the decentralisation process is that power has been "granted" to local authorities by the state. ${ }^{(41)}$ The PMC is actually not a social organisation, as its work and operations are a collaboration between the government and judicial bureau to reduce conflict and address protests at the grassroots level. Rather, it is a case of DMDR for fulfilling the political task of controlling and suppressing collective actions and protests that could challenge the regime's legitimacy and threaten social stability while also resolving social disputes for local citizens.

As a social means of dispute resolution, the OCPSS is by nature a government operated non-government organisation (GONGO), as it is a semigovernmental institution that gets almost half of its funding from government organisations despite its independent registration under the Civil Affairs Bureau. The rationale for the local government's support and promotion of OCPSS in defusing social conflicts lies in the increasing recognition of its practice by higher-level authorities as it connects citizens with the local government as well as preventing potential collective actions that may result in social unrest at the grassroots level. The OCPSS represents an integration of state laws (guofa 国法) and reason/moral principles (qingli 情理) by employing apology, verbal promises or written agreements, shared meals, and so on to lend the mediated resolution a ritualistic confirmation among conflicting parties. The practice of OCPSS has also spread to others cities as a successful example of "local social innovation management."

\footnotetext{
38. Interview with Mrs. Gong in T City, 24 August 2014.

39. Ng Kwai Hang and He Xin, "Internal Contradictions of Judicial Mediation in China," art. cit., p. 308.

40. Interview with Ms. Huang in S City, 22 July 2014

41. Xueguang Zhou, "Unorganized Interests and Collective Action in Communist China," American Sociological Review, Vol. 58, No. 1, February 1993, pp. 54-73.
} 
However, the three examples representing DMDR in China demonstrate a deliberate attempt by the authoritarian regime to manage social disputes in the absence of an active civil society and a dependent judiciary while developing state-led plural and diversified social governance. ${ }^{(42)}$ Since the mid-1990s, the Party-state in China has sought to raise its regulatory and governance capacity in order to maintain both growth and stability because localised rebellion is seen as a threat to the common good. ${ }^{(43)}$ DMDR could, to a large extent, fulfil this task in that it possesses a collaborative network of local Party organisations, bureaucratic agencies, public security sectors, law firms, and courts, deals with disputes in a diversified way that can weaken or eliminate any "dangerous factors" within them, and invites social methods of dispute resolution in conjunction with strong state intervention.

\section{Conclusion}

Given the Party-state's drive to contain perceived political threats, rule of law still faces severe predicaments in contemporary China. However, the reality of rising income disparity, high unemployment, high levels of mobility and migration, rampant corruption, crime, and social disorder has compelled the government to take action to effectively resolve social disputes and enhance the legitimacy of its rule. DMDR, as a coordinated mechanism for settling social disputes, can play a substantial role in reducing grievances and defusing conflicts and protests through judicial, administrative, and social means. More specifically, it provides an additional method in the current situation to overcome the limitations of both the litigation and non-litigation systems. Community judges, people's mediation centres, and the Onestop Comprehensive Petition Service Station, representing diversified methods of dispute resolution, serve as a bridge between the Party-state and local citizens for communication and negotiation, thereby reducing the likelihood of collective protest and large-scale conflicts targeting the government.

However, the implementation of DMDR in different places in China also demonstrates that it creates incentives and opportunities for local authorities to gain political credit for maintaining social stability by preventing potential large-scale protests or intractable disputes and achieving dispute resolution. Current social conflicts compel the regime to seek all possible means to maintain stability, even at the expense of laws. DMDR therefore gains its institutional rationality and basis to be promoted by the Partystate in that it serves the dual purpose of enhancing problem-solving and dispute resolution at the local level as well as providing local officials with achievements for their professional appraisals. It is, in fact, the result of a complex state-society interaction greatly influenced by internal Party disciplinary regulations governing official response to citizen protests. This interaction demonstrates the satisfaction of official demands through dispute resolution on the one hand and political achievements and governance on the other.

These examples of DMDR underline the current tendency to combine legal and extra-legal methods to manage social disputes in Chinese local practice. However, these solutions are far from realising "judicial independence." Judges' engagement with government agencies and administrative departments in coping with social disputes undermines their institutional autonomy and neutral stance when settling disputes. It would be wiser to empower social organisations by offering them more resources and selfgovernance in order to develop effective methods of dispute resolution and build up harmonious relationships within society. Recent developments indicate that the government has realised the importance of cooperating with society to reach broader goals, and this may provide social groups with more flexibility and freedom in their daily operations. In a context in which civil society organisations are under great political pressure, with many arrests and NGO closures at the end of 2015, these kinds of local initiatives serve to facilitate state-society relationships and avoid the escalation of issues into social conflict.

I Jieren Hu (corresponding author) is associate professor in the Law School/Intellectual Property Institute at Tongji University, Shanghai, and research fellow at the Centre for Social Governance Research at Fudan University, Shanghai.

RM 2111, 21/F, Zonghe Bldg., Law School/IP Institute, Tongji University, 200092 Shanghai, China (besthujieren@tongji.edu.cn).

I Yang Zheng is a postgraduate student majoring in political theory at the School of Politics and International Relations, Tongji University, Shanghai.

Postgraduate Workroom 2022, 20/F, Tongji A Building, School of Politics and International Relations, Tongji University, No. 1239 Siping Road, 200092 Shanghai, China (zhengyang_1990@126.com).
42. B. Michael Frolic, "State-Led Civil Society?", in Timothy Brook and B. Michael Frolic (eds), Civil Society in China, New York, M. E. Sharp, 1997, pp. 46-67.

43. Jae Ho Chung, Hongyi Lai, and Ming Xia, "Mounting Challenges to Governance in China: Surveying Collective Protestors, Religious Sects and Criminal Organizations," art. cit., p. 30 